\section{Oryslava BILYK, \\ orcid.org/0000-0002-9306-8818 \\ Lecturer at the Department of Foreign Languages \\ Lviv Polytechnic National University \\ (Lviv,Ukraine)oryslava@gmail.com}

Oksana PUHA, orcid.org/0000-0003-0406-2615

Lecturer of the Department of Foreign Languages Lviv Polytechnic National University

(Lviv, Ukraine)Oksana.hrynchuk2@gmail.com

\title{
STRUCTURAL AND SEMANTIC PECULIARITIES OF ENGLISH COLOUR-NAMING COMPOUNDS AND WAYS OF RENDERING THEIR MEANINGS (BASED ON CH. DICKENS'S LITERARY WORK “OLIVER TWIST")
}

\begin{abstract}
The article gives the profound analysis of colour-naming compounds chosen from Charles Dickens's novel 'Oliver Twist'. The productive types of colour-naming compounds have been defined, their semantic and structural peculiarities have been revealed as well as their functioning in the literary discourse. The translation techniques used by the Ukrainian translators in order to render the meanings of colour-naming compounds into the target language have been analyzed. The analysis has shown that the Ukrainian translators in the process of revealing colour-naming compounds used the following translation strategies: paraphrasing, word to word translation, literal translation and omission. The semantic analysis of English colour-naming compounds has proved that they are mostly used in order to give either positive or negative evaluation of a person, to describe the appearance of a person or to display his/her psycho-emotional state. Color-naming compounds perform a descriptive rather than an evaluative function and are perceived as an integral unity rather than individual meanings of their components. The black-and-white palette of colors predominates in the work to depict the joyless childhood of orphans, the hardships of life, the attitude of society to orphanages. The author uses brighter color scheme to depict a happy ending, embodying his desire for the triumph of justice. In Ukrainian translations, readers have the opportunity to feel and experience together with the main characters all the sufferings that they come across in their lives, as Ukrainian translators tried to reproduce the meaning of color-naming compounds as fully as possible in the target language. Compounds that contain color-naming are mostly two- or three-membered constructions that consist of a noun and one or two adjectives to denote a color, its hue or saturation.
\end{abstract}

Key words: source text, target language, colour-naming compound, structure, semantics, translation technique.

Орислава БІЛИК, orcid.org/0000-0002-9306-8818 викладач кафедри іноземних мов Національного університету «Львівська політехніка» (Львів, Україна) oryslava@gmail.com

Оксана ПУГА,
оrсid.org/0000-0003-0406-2615
викладач кафедри іноземних мов
Національного університету «Львівська політехніка»
(Львів, Україна) Oksana.hrynchuk2@gmail.com

\section{СТРУКТУРНО-СЕМАНТИЧНІ ОСОБЛИВОСТІ АНГЛІЙСЬКИХ СКЛАДНИХ КОЛЬОРОНАЙМЕНУВАНЬ ТА СПОСОБИ РОЗКРИТТЯ ЇХ ЗНАЧЕННЯ (НА ОСНОВІ РОМАНУ Ч. ДІККЕНСА «ОЛІВЕР ТВІСТ»)}

У статті було проведено грунтовний аналіз складних кольоронайменувань, обраних із роману Чарльза Діккенса «Олівер Твіст». Визначено продуктивні типи кольороназв, виявлено їх семантичні та структурні особливості, а також функиіонування в літературному дискурсі. Проаналізовано способи перекладу, щзо використовувалися украӥнськими перекладачами для передачі значення складних слів на позначення кольору у множинних перекладах. Аналіз показав, щэо украйнські перекладачі для розкриття семантики кольронайменувань 
використовували такі перекладацькі стратегії як перифраза, дослівний та літературний переклад. У результаті проведеного семантичного аналізу складних кольороназв було доведено, щзо вони в основному використовувалися для того, щзоб дати позитивну чи негативну оцінку персонажу, описати зовнішній вигляд людини або показати iї психоемоційний стан. Складні кольороназви виконують більшою мірою описову, ніж оцінну функцію, та сприймаються як єдине иіле, а не окремо взяті значення їх компонентів. Чорно-біла палітра кольорів переважає у творі для зображення безрадісного дитинства сиріт, тяжких життєвих випробувань, ставлення суспільства до сирітських притулків. Автор вдається до використання більш яскравих кольорів для зображення шуасливого кіния, втілюючи своє прагнення до торжества справедливості. В українських перекладах читач має змогу відчути та пережити разом із головними героями всі ті випробування, які зустрічаються на їх шляху, оскільки украӥнські перекладачі намагалися якнайповніме відтворити значення кольороназв засобами рідної мови. Складні слова, щуо містять назву кольору, є двочленними або тричленними конструкціями, які складаються з іменника та одного чи двох прикметників на позначення кольору, його відтінку чи насиченості.

Ключові слова: оригінал, мова перекладу, кольоронайменування, структура, семантика, спосіб перекладу.

Introduction. The question of forming English compounds was investigated by a large number of both native and foreign scientists. Despite the constant interests of linguists to the problem of English word-building, some questions have not been fully investigated. The problems of forming English colour-naming compounds, defining the productive types of compounds with names of colour and distinguishing structural types of colour-naming compounds in modern English need further investigation.

The absence of a complex investigation of English colour-naming compounds leads to the choice of the theme of the investigation. The aim of this article is to focus the attention on coining English colour-naming compounds with the aim of defining their productive types, distinguishing semantic and structural peculiarities of English and Ukrainian compounds and derivatives with the names of colour, choosing the adequate ways of rendering the meanings of compounds.

Verbal expression of colour is reflected in all its diversity - one of the most interesting and most difficult tasks of the literary discourse. There are numerous examples of the use of compound words that occur in different types of word-building which are of great interest for the scientific study as English colour-naming compounds are logical-semantic units that sometimes substitute comparative phrases or even sentences. The use of color is caused by the author's desire to depict a thing or a person in a more expressive, emotional way, to add more vividness as the ordinary way of expression is not able to create such effects (Pastushenko, 1998: 12).

The subject of the study is colour-naming compounds selected from the Ukrainian translations of Charles Dickens's novel 'Oliver Twist' by M. Pinchevsky and V. Chernyahivs'ka.

The object of the research is semantic and structural peculiarities of English colour-naming compounds.

The article focuses on the investigation of semantic as well as structural peculiarities of English colour-naming compounds in the literary work of the famous English writer Charles Dickens and ways of rendering their meanings into Ukrainian.

That's why the purpose of the investigation consists in the investigation of the main semantic and structural peculiarities of English colour-naming compounds in a literary discourse and ways of rendering their meanings in the Ukrainian translations.

In order to achieve the aim of the investigation the following tasks should be solved: to select colour-naming compounds from the novels mentioned above; to define the productive types of coining English compounds with the names of colours; to reveal the meanings of colour-naming compounds in both languages; to define the colour scheme Charles Dickens often used in his literary works; to compare translation techniques used for rendering the meanings of colour-naming compounds. The novelty of the investigation lies in the fact that the colour-naming compounds were analyzed by means of componential and contextual analysis that help us to choose the most productive types.

Recent research and publications. The linguist A.K. Krainyak investigated compounds with the first verbal component (semantic-cognitive aspect), pragmatic-stylistic aspect of their forming and functioning (T. M. Moros), the semantics and structure of English compounds and derivatives with the suffix $-e r$ (L. F. Solovjova), the productive types of compound adjectives and verbs in modern English (L. Y. Omelchenko), cognitive-onomasiological aspect of English colour-naming compounds (O. V. Demenchuk) and many others.

The native linguists O. V. Demenchuk, O.S. Kubryakova define a colour-naming compound as 'an integrally designed unit consisting of two components - colour-naming and a meaningful lexeme of a definite structure that represents a certain connection of meaning and form' (Demenchuk, 2003: 9).

Results and discussion. The process of coining compound words doesn't lose its significance on the modern stage of the English language development 
and still remains the object of numerous linguistic investigations. Thoughts can be expressed, things and phenomena can be described succinctly with the help of compound words (Demenchuk, 2003: 11). The main reason of coining compounds is an attempt to name a thing by means of one word instead of being described by bulky combinations or even sentences.

Charles Dickens tactfully manipulates colournaming compound epithets to achieve a certain dramatic purpose. It is observed that his language being fresh, vibrant, exuberant makes use of the number of colour-naming compounds which function as modifiers and they are descriptive rather than evaluative in nature, they specify some qualities or features of a thing/human being represented by the noun or pronoun described by it (Bohachevs'ka, 2007: 12). They are also used to reinforce clarity and facilitate vividness, they should be perceived as a single unit but not as individual combination of words because they work together to modify, describe, limit or quantify a noun (Koval's'ka, 2001: 10). They are mostly used to describe abstract or concrete nouns such as: abstract (feelings and passion, misery, time; problems of human society (love, fury, death, groans, revenge, mourning, etc.) or concrete (nature, characters, parts of their body, etc.).

Ch. Dickens's compound lexemes are not very various in structure but they are mostly used in the stylistic functions of comparative and descriptive-evaluative epithets which play an important part in image creation in the narrative context (Bohachevs'ka, 2007: 7).

Compound words in which two stems often incompatible are joined together are of extraordinary interest for the investigation, especially we were interested in Charles Dickens's use of colour scheme in order to depict different events, phenomena, describe characters, landscapes, etc. By means of unexpected combinations some incompatible stems in one word, the author tried to achieve the greatest artistic effect of image-sensory perception.

Different translations of the same literary work is always desirable since only the original source is unique and each interpretation reveals some new details, helps to understand the source text much deeper. For these reasons, the presence of two Ukrainian translations of the novel 'Oliver Twist' was good for our comparative analysis. The comparative analysis of two Ukrainian translations helped to reveal different techniques the translators used in their attempt to preserve the unique style of the author (Koval's'ka, 2001: 6).

Depending on the complexity of meaning contained in the source-language compound, it can be expressed in the target language in some ways:
1) by a single word: Sitting in among the wares he dealt in, by a charcoal stove, made of old bricks, was a grev-haired rascal, nearly seventy years of age [7, p. 409];

I серед усіх иих покидьків, які слугували предметом купівлі-продажу, біля складеної зі старої цегли пічки, де догоряло вугілля, сидів сивий шахрай доволі похилого віку [6, с. 402];

2) by free combinations of words: and two scowling eyes; one of which displayed various particoloured symptoms of having been recently damaged by a blow [7, p. 409].

Коли гість скинув хустку, то виявилося, що обличчя в нього широке, грубе, днів зо три не голене, очі похмурі й одне з них прикрашене різнобарвним синцем, що свідчив про недавне тілесне ушкодження [5, с. 358];

3) by a sentence or a longer explanation: This guileless confectioner was not by any means sober, and was black-eved in the green stage of recovery which was painted over [7, p. 260].

Цей липовий представник кондитерського фаху був виразно п'януватий, а під оком у нього красувався задавнений уюе синець, підмащений фарбою [5, с. 187];

4) by omission: They left the high-road, by a wellremembered lane, and soon approached a mansion of dull red brick, with a little weathercock-surmounted cupola, on the roof, and a bell hanging in it [7, p. 26].

Вони звернули з дороги на пам'ятну стежину $i$ незабаром підійшли до иегляного будинку 3 увінчаною флютером невеликою круглою башточкою зі дзвоном [5, с. 18];

5) by idiomatic expression: In time I were able to keep him, and I kept him till he went off in a purple leptic fit [7, p. 79].

3 часом я вже міг $і$ батька утримувати і таки утримував, поки його не побив греиь [6, с. 65].

The analysis has shown that the translators in the process of revealing colour-naming compounds used four basic translation strategies: paraphrasing which involves explanatory and stylistic paraphrase; word to word translation which involves using a compound of a similar meaning and form and using a compound of a similar meaning but a dissimilar form; literal translation and omission. The analysis of particular samples was intended to illustrate the choices of particular strategies in different Ukrainian translations. In the Ukrainian translations of Ch. Dickens's novel done by M. Pinchevskiy, V. Chernyahivs'ka the translators tried to stick to the source text as close as possible by trying to find the existing Ukrainian equivalents. In this way they tried to preserve the effect and meaning of the 
original text. In some places they used literal translation which caused an effect of foreign interpretation. The analysis of the translation of colour-naming compounds in Charles Dickens's literary work has shown that translating them from the original novel required a lot of knowledge about the structure and the meaning of a compound and the adequate choice of rendering its meaning on the part of the translator. On the whole, the usage of different strategies in translating compounds in a literary discourse illustrates the diverse ways of choosing the adequate translation strategies in the target language: She came to the gate, and positively reeled back when she saw me so changed; her walnut-shell countenance likewise, turned from brown to green and yellow [7, p. 198] Вона вийшла відімкнути хвіртку, мало не зімліла, побачивши, яким я став, а ії горіхово-шкаралуписте личко з бурого перетворилось на зелено-жсовте [6, с. 149].

However, compounds express the uniqueness of the language and culture in which they are originated and, therefore, the strategies for their translation need careful consideration and the translators need deep knowledge of the source and target languages and cultures.

The literary work of the famous English novelist Charles Dickens under research is an extremely important aspect of literary understanding of the history of the mid-nineteenth century England. No doubt all the new generation of readers has discovered its unique character, so gracefully manifested in the novel under investigation. With unique skills and specific attitude the translators tried to describe the life of the main characters. Together with them, the readers can feel piercing noise, cold wind of trees, branches scratching on a windowpane as well as the warmth from the fireplace heat, blinding shine of dishes on the wide oak shelves. But the uniqueness of the novel is a realistic idea embodied in it, that is why seeking adequate ways of conveying passion, hatred and other human feelings and emotions as accurately and closely to the original as possible was the task of the Ukrainian translators.

In the process of semantic analysis of English colour-naming compounds we can conclude that they are mostly used in order to give either positive or negative evaluation of a person: a) to describe the appearance of a person: and we are straightway transported to the great hall of the castle; where a grey-headed seneschal sings a funny chorus with a funnier body of vassals... [7, p. 137] і ми зненацька опинясмось у великому залі замку, де сивоголовий сенешаль виконує забавну пісеньку у супроводі хору ще забавніших васалів.... [5, с. 112] b) to display psycho-emotional state of a person: it was at this still and silent hour, he sat watching in his old lair, with face so distorted and pale, and eyes so red and blood-shot, that he looked less like a man, than like some hideous phantom, moist from the grave, and worried by an evil spirit [7, p. 473]. О иій-от тихій, безгомінній порі він сидів у своєму лігві. Обличчя його було таке бліде й перекошене, а очі такі червоні, наче налиті кров'ю, щзо він скидався не на людину, а скоріш на потворний привид, який постав, розтривожений злим духом, прямо з домовини [6, с. 412].

To sum up, the Ukrainian translators used a combination of various translation techniques in order to reveal the semantic, structural and functional peculiarities of English colour-naming compounds of the original text into the Ukrainian language. But sometimes they omit the name of a colour component in a compound as in the following example: 'what makes you take so much pains about one chalk-faced kid. when you know there are fifty boys snoozing about Common Garden every night, as you might pick and choose from?' [7, p. 194] Чому ти морочишся 3 иим хирлявим иммаркачем, коли Коммон-Гарден щовечора аж кишить хлопчаками, з яких ти міг би вибрати куди кращчого? [5, с. 98].

In spite of their own improvisation in certain places of the original text, the sense of the original is adequately rendered by means of choosing the similar Ukrainian colour-naming compounds. The Ukrainian translators tried to preserve the structure and the so-called 'spirit' of the English original text, though there were numerous inaccuracies and slight transformations. The comparative-typological analysis of revealing the meaning of colour-naming compounds can help the investigators to evaluate the appropriateness of the chosen translation techniques.

Conclusions. While analyzing the literary work by Charles Dickens we have come across numerous examples of compounds in which the author mentioned above used various colours and their shades. Among the rich variety of colours dark-colour scheme dominates in his novel serving various means of depicting physical appearance of the main characters, their clothes, feelings and emotions.

The investigation has shown that concerning semantic peculiarities, colour-naming compounds in most cases are used in their direct meanings with a few exceptions. Black and white are the most widely represented English colours used in Charles Dickens's literary work. The meanings of colour components brown and yellow are the least frequently used and the examples of metaphorical usage of these constituents are quite rare. 
The investigation of structural peculiarities revealed that the structure $a d j+n$ is the most common in the formation of colour-naming compounds in which the left-hand constituent is in the attributive relation to the right-hand one and modifies it. The second widely-used structural type is $n+$ adj. The noun which is on the left side modifies the adjective by giving associations with a certain colour. The third structural type is adj + adj in which two colours are of equal importance or they are mixed together.

The structural variety is not restricted to compounding. Suffixes added to one of the stems of colour-naming compounds made the nominations more expressive, diverse and there are numerous examples to illustrate it.

The contrastive analysis helped to evaluate the adequacy of depicting the multifaceted and colourful world in which the main characters lived, their feelings and sufferings in the Ukrainian translations.

The problem of coining compounds with the name of colour on the basis of idiomatic meanings has not found the adequate coverage in the works of modern scientists yet, so it may be a prospect for further investigation.

\section{BIBLIOGRAPHY}

1. Богачевська Л. О. Чарлз Діккенс і українська література : проблеми рецепції і типології : автореф. дис. ... канд. філол. наук. Тернопіль, 2007. 20 с.

2. Деменчук О. В. Колоративна композита в англійській мові: когнітивно-ономасіологічний аспект : автореф. дис... канд. філол. наук. Київ, 2003. 19 с.

3. Ковальська I. В. Колористика як перекладознавча проблема (на матеріалі українських і англомовних текстів) : автореф. дис...канд. філол. наук. Львів, 2001. 20 с.

4. Пастушенко Т. В. Колірна номінація як елемент вторинної мовної картини світу (на матеріалі сучасної англійської мови) : автореф. дис. ... канд. філол. наук. Київ, 1998. 20 с.

5. Діккенс Ч. Олівер Твіст : роман / Чарлз Діккенс. пер. з англ. В. Черняхівської. Харків : Фоліо, 2012. 378 с.

6. Діккенс Ч. Пригоди Олівера Твіста : роман / Чарлз Діккенс. пер. з англ. М. Пінчевський, Г. Пінчевська-Чекаль, О. Терех. Київ : Дніпро, 1987. 423 с.

7. Dickens Ch. Oliver Twist. URL : https://booksonline.com.ua/viewphpbook=165033.

\section{REFERENCES}

1. Bohachevs'ka L. O. Charlz Dikkens i ukrayins'ka literatura : problemy retseptsiyi i typolohiyi [Charles Dickens and Ukrainian literature: problems of reception and typology].Ternopil', 2007. 20 p. [in Ukrainian].

2. Demenchuk O. V. Koloratyvna kompozyta v anhliys'kiy movi: kohnityvno-onomasiolohichnyy aspekt [Color-naming compounds in English: cognitive-onomasiological aspect]. K., 2003. 19 p. [in Ukrainian].

3. Koval's'ka I.V. Kolorystyka yak perekladoznavcha problema (na materiali ukrayins'kykh i anhlomovnykh tekstiv). [Coloristics as a translation problem (based on Ukrainian and English texts)]. Lviv, 2001. 20 p. [in Ukrainian].

4. Pastushenko T. V. Kolirna nominatsiya yak element vtorynnoyi movnoyi kartyny svitu (na materiali suchasnoyi anhliys'koyi movy). [Color nomination as an element of the secondary linguistic picture of the world (on the material of modern English)]. K., 1998. 20 p. [in Ukrainian].

5. Dickens Ch. Oliver Twist: novel / translated by V. Chernyakhivs'ka. Kharkiv: Folio, 2012. 378 p. [in Ukrainian].

6. Dickens Ch. Adventures of Oliver Twist: novel / translated by M. Pinchevs'ky, H. Pinchevs'ka-Chekal', O. Terekh. K.: Dnipro, 1987. 423 p. [in Ukrainian].

7. Dickens Ch. Oliver Twist: https://booksonline.com.ua/ viewphpbook=165033. [in English]. 